\title{
Pyruvate carboxylase as an anaplerotic enzyme in Corynebacterium glutamicum
}

\author{
Petra G. Peters-Wendisch, Volker F. Wendisch, Susanne Paul, \\ Bernhard J. Eikmanns and Hermann Sahm \\ Author for correspondence: Bernhard J. Eikmanns. Tel: +49 2461 613967. Fax: +492461612710. \\ e-mail : b.eikmanns@kfa-juelich.de
}

Institut für Biotechnologie, Forschungszentrum Jülich, D-52425 Jülich, Germany

\begin{abstract}
The recent discovery that phosphoenolpyruvate carboxylase (PEPCx) is dispensable for growth and lysine production in Corynebacterium glutamicum implies that this organism possesses (an) alternative anaplerotic enzyme(s). In permeabilized cells of $C$. glutamicum, we detected pyruvate carboxylase (PCx) activity. This activity was effectively inhibited by low concentrations of ADP, AMP and acetyl-COA. PCX activity was highest [45 $\pm 5 \mathrm{nmol} \mathrm{min}^{-1}\left(\mathrm{mg}\right.$ dry wt) $\left.{ }^{-1}\right]$ in cells grown on lactate or pyruvate, and was about two- to threefold lower when the cells were grown on glucose or acetate, suggesting that formation of PCX is regulated by the carbon source in the growth medium. In cells grown at low concentrations of biotin $\left(<5 \mu \mathrm{g} \mathrm{I}^{-1}\right)$, PCx activity was drastically reduced, indicating that the enzyme is a biotin protein. Growth experiments with the wild-type and a defined PEPCX-negative mutant of $C$. glutamicum on glucose showed that the mutant has a significantly higher demand for biotin than the wild-type, whereas both strains have the same high biotin requirement for growth on lactate and the same low biotin requirement for growth on acetate. These results indicate that (i) PCx is an essential anaplerotic enzyme for growth on glucose in the absence of PEPCx, (ii) PCX is an essential anaplerotic enzyme for growth on lactate even in the presence of PEPCx, and (iii) PCx has no anaplerotic significance for growth on acetate as the carbon source. In support of these conclusions, screening for clones unable to grow on a minimal medium containing lactate, but able to grow on a medium containing glucose or acetate, led to the isolation of PCx-defective mutants of $C$. glutamicum.
\end{abstract}

Keywords: Corynebacterium glutamicum, anaplerotic reactions, pyruvate carboxylase, phosphoenolpyruvate carboxylase

\section{INTRODUCTION}

Bacteria require anaplerotic reactions for continuous replenishment of the tricarboxylic acid (TCA) cycle with $\mathrm{C}_{4}$-dicarboxylic acids used for anabolic purposes, for example amino acid biosynthesis (Kornberg, 1966). In most organisms, the anaplerotic function during growth on glucose is mediated by either phosphoenolpyruvate (PEP) carboxylase (PEPCx; reaction 1) or pyruvate carboxylase (PCx; reaction 2) (Wood \& Utter, 1965 ; Kornberg, 1966). However, some bacteria use PEP carboxykinase (PEPCk) or PEP carboxytransphos-

Abbreviations: $C T A B, N$-cetyl- $N, N, N$-trimethylammonium bromide; GOT, glutamate-oxaloacetate transaminase; $P C X$, pyruvate carboxylase; PEP, phosphoenolpyruvate; PEPCK, PEP carboxykinase; PEPCX, PEP carboxylase; TCA, tricarboxylic acid; WT, wild-type. phorylase as anaplerotic enzymes (Wood \& Utter, 1965; Kornberg, 1966; Schobert \& Bowien, 1984), and some Arthrobacter strains even use the glyoxylate cycle as an anaplerotic sequence for growth on glucose (Krulwich $\&$ Pelliccione, 1979).

$$
\begin{aligned}
& \mathrm{PEP}+\mathrm{HCO}_{3}^{-} \stackrel{\mathrm{PEPCx}}{\longrightarrow} \text { Oxaloacetate }+\mathrm{P}_{\mathrm{i}} \\
& \text { Pyruvate }+\mathrm{HCO}_{3}^{-}+\mathrm{ATP} \stackrel{\mathrm{PCx}}{\rightleftharpoons} \text { Oxaloacetate }+\mathrm{ADP}+\mathrm{P}_{\mathrm{i}}
\end{aligned}
$$

Corynebacterium glutamicum is an aerobic, Grampositive biotin auxotroph that grows on a variety of sugars and organic acids, and is widely used in the industrial production of amino acids, for example Lglutamate and L-lysine (Liebl, 1991). During growth on glucose, the anaplerotic function in C. glutamicum has 
generally been attributed to PEPCx (Kinoshita, 1985; Liebl, 1991). This enzyme is present with relatively high specific activities in all C. glutamicum strains tested (Ozaki \& Shiio, 1969; Mori \& Shiio, 1985a; Eikmanns et al., 1989; Jetten et al., 1994; Gubler et al., 1994). From C. glutamicum subsp. flavum, the enzyme was purified and shown to be activated by acetyl-CoA and fructose1,6-bisphosphate and inhibited by aspartate and 2oxoglutarate (Mori \& Shiio, 1985a, b). These regulatory properties, as well as carbon flux studies (Vallino \& Stephanopoulos, 1993), suggested a key role of PEPCx as an anaplerotic enzyme, and thus in carbon flow to amino acids derived from the TCA cycle. However, comparison of defined PEPCx-negative mutants with the parent strains of C. glutamicum showed identical growth characteristics on all media tested, and identical capacity for lysine production (Peters-Wendisch et al., 1993; Gubler et al., 1994). These surprising results showed that PEPCx is dispensable as an anaplerotic enzyme in C. glutamicum, and indicated that different anaplerotic enzymes operate in this organism.

Enzyme studies with cell-free extracts of C. glutamicum further revealed that, besides PEPCx, the organism possesses PEPCk (Jetten \& Sinskey, 1993; PetersWendisch et al., 1993). The activity of this enzyme in the direction of oxaloacetate synthesis was, however, completely inhibited by low concentrations of ATP (Jetten \& Sinskey, 1993), which makes it likely that the PEPCk of C. glutamicum is involved in gluconeogenesis rather than in anaplerosis. Genetic experiments as well as in vivo ${ }^{13} \mathrm{C}$-labelling experiments with $\mathrm{C}$. glutamicum wild-type (WT) and the PEPCx-negative mutant, and subsequent ${ }^{1} \mathrm{H}$-NMR analysis, excluded operation of the glyoxylate cycle as an anaplerotic sequence during growth on glucose, and identified the anaplerotic pathway in the presence and absence of PEPCx to involve carboxylation of PEP and/or pyruvate (PetersWendisch et al., 1996). These findings prompted us to thoroughly test for the presence of PCx in C.glutamicum. During the course of these experiments, we detected PCx activity in permeabilized cells. Here, we characterize this activity and examine its significance for growth of C. glutamicum on different substrates in the presence and absence of PEPCx.

\section{METHODS}

Bacterial strains and growth conditions. We used $C$. glutamicum wild-type (ATCC 13032), the restriction-deficient C. glutamicum R127 (Liebl \& Schein, 1990), the lysine producer C. glutamicum MH20-22B (Schrumpf et al., 1992), the PEPCx-negative strain C. glutamicum WT-PP (PetersWendisch et al., 1993) and Bacillus subtilis DB104 (Kawamura \& Doi, 1984). Luria-Bertani (LB) medium or $2 \times$ TY broth were used as complex media (Sambrook et al., 1989). The minimal media for growth of C. glutamicum were described previously (Eikmanns et al., 1991). They contained $4 \%(\mathrm{w} / \mathrm{v})$ glucose, $2 \%(\mathrm{v} / \mathrm{v})$ sodium $\mathrm{D}, \mathrm{L}$-lactate, $2 \%(\mathrm{w} / \mathrm{v})$ sodium pyruvate or $2 \%(\mathrm{w} / \mathrm{v})$ potassium acetate as carbon sources. When appropriate, kanamycin $\left(50 \mu \mathrm{g} \mathrm{ml}^{-1}\right)$ was added to the medium. The cells were grown aerobically as $60 \mathrm{ml}$ cultures in $500 \mathrm{ml}$ baffled Erlenmeyer flasks at $30^{\circ} \mathrm{C}$. Growth was measured as increase in $\mathrm{OD}_{600}$.

For isolation of PCx-defective mutants, C. glutamicum R127 cells grown overnight on $2 \times$ TY broth were incubated at $25^{\circ} \mathrm{C}$ with NMG ( $N^{\prime}$-methyl- $N^{\prime}$-nitro- $N$-nitrosoguanidine) $\left(0.25 \mathrm{mg} \mathrm{ml}^{-1}\right)$ for $15 \mathrm{~min}$. The cells were then washed twice in $50 \mathrm{mM}$ Tris $/ \mathrm{HCl}$ buffer, $\mathrm{pH} 7$, resuspended in the same buffer containing $30 \%(\mathrm{v} / \mathrm{v})$ glycerol and stored at $-20^{\circ} \mathrm{C}$ until used. To screen for PCx-negative mutants, aliquots of the cell suspension were spread on LB agar and successively replicaplated on minimal medium agar containing glucose, lactate, pyruvate or acetate as carbon sources.

PCx assay with permeabilized cells. PCx activity in permeabilized cells of $C$. glutamicum was determined by the discontinuous glutamate-oxaloacetate transaminase- (GOT-) coupled assay described by Fisher \& Magasanik (1984). For this assay, cells were grown in minimal medium to the exponential growth phase, washed once in $20 \mathrm{ml} 50 \mathrm{mM}$ Tris $/ \mathrm{HCl}$ buffer, $\mathrm{pH} 6.3$, containing $50 \mathrm{mM} \mathrm{NaCl}$, resuspended to an $\mathrm{OD}_{600}$ of 150 in $100 \mathrm{mM}$ HEPES buffer, $\mathrm{pH} 7 \cdot 5$, containing $20 \%(\mathrm{v} / \mathrm{v})$ glycerol and then frozen at $-20{ }^{\circ} \mathrm{C}$. For permeabilization, the frozen cells were thawed slowly on ice and then mixed with a solution of $10 \%(\mathrm{w} / \mathrm{v})$ $\mathrm{CTAB}$ ( $N$-cetyl- $N, N, N$-trimethylammonium bromide) to give a final concentration of $0.3 \%$. This cell suspension was used directly to assay for $\mathrm{PCx}$ by the formation of oxaloacetate from pyruvate, $\mathrm{HCO}_{3}^{-}$and $\mathrm{ATP}$, and subsequent conversion of the oxaloacetate to aspartate with GOT. The standard

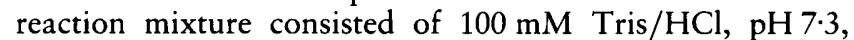
$25 \mathrm{mM} \mathrm{NaHCO}, 20 \mathrm{mM}$ pyruvate, $4 \mathrm{mM}$ ATP, $2 \mathrm{mM}$ glutamate, $20 \mu \mathrm{M}$ pyridoxal phosphate and 2 units (U) of pig heart GOT in a final volume of $1 \mathrm{ml}$. The reaction was started by adding up to $50 \mu \mathrm{l}$ of the cell suspension. After incubation of the reaction mixture at $30^{\circ} \mathrm{C}$ for 60,90 or $120 \mathrm{~s}$, the reaction was terminated by boiling for $5 \mathrm{~min}$. After incubation in icewater for $5 \mathrm{~min}$, the cell debris was removed by centrifugation for $20 \mathrm{~min}\left(13000 \mathrm{~g}, 4^{\circ} \mathrm{C}\right)$ and aspartate was quantified as its $o$-phthaldialdehyde derivative by reversed-phase HPLC (Schrumpf et al., 1992). One unit of PCx activity corresponds to $1 \mu \mathrm{mol}$ aspartate formed per min. Cell mass was determined by measuring $\mathrm{OD}_{600}\left(\mathrm{OD}_{600}=1\right.$ corresponded to $0.3 \mathrm{mg}$ dry wt $\mathrm{ml}^{-1}$ ). Treatment of the cells with concentrations of CTAB higher or lower than $0.3 \%$ decreased the specific PCx activity, and cells not treated with CTAB showed no PCx activity.

In the ${ }^{13} \mathrm{C}$-labelling experiments, $\mathrm{NaHCO}_{3}$ in the $\mathrm{PCx}$ reaction mixture was replaced by $\mathrm{H}^{13} \mathrm{CO}_{3}^{-}(99 \%$ atom-enrichment; Cambridge Isotope Laboratories), or $70 \%$ of the unlabelled pyruvate was replaced with either $\left[2-{ }^{13} \mathrm{C}\right]$ pyruvate or [3${ }^{13} \mathrm{C}$ )pyruvate (each $99 \%$ atom-enrichment; Isotech). The aspartate formed in the assay was purified by cation-exchange chromatography on an Ultrapac $11 \mu$ resin column (Pharmacia) using an FPLC system from Sykam as described previously (Peters-Wendisch et al., 1996). Triethylamine (0.2 M) with a $\mathrm{pH}$ gradient from 3.2 to 10.5 was used for elution in $1 \mathrm{ml}$ fractions. The fractions containing aspartate were combined, vacuum-dried, resuspended in $0.6 \mathrm{ml} \mathrm{D} 2 \mathrm{O}$ and then subjected to ${ }^{1} \mathrm{H}-\mathrm{NMR}$ spectroscopy. As an internal standard, sodium 3trimethylsilyl- $\left[2,2^{\prime}, 3,3^{\prime}-\mathrm{D}_{4}\right]$ propionate was included at $2 \mathrm{mM}$ in each sample.

Enzyme assays with cell-free extracts. C. glutamicum cells were grown in minimal medium to the exponential phase, washed twice in $20 \mathrm{ml} 100 \mathrm{mM}$ Tris/ $\mathrm{HCl}$ buffer, $\mathrm{pH} \mathrm{7}$, and resuspended in $1 \mathrm{ml}$ of the same buffer containing $20 \%(\mathrm{v} / \mathrm{v})$ glycerol. After disruption of the cells by sonication (Eikmanns et al., 1991) and subsequent centrifugation $(13000 \mathrm{~g}, 30 \mathrm{~min}$, $\left.4{ }^{\circ} \mathrm{C}\right)$, the supernatant was used for the assays. Protein was 
measured by the biuret method (Gornall et al., 1949) with bovine serum albumin as standard.

PCx in cell-free extracts of C. glutamicum was assayed at $30^{\circ} \mathrm{C}$ by three different methods. The first was that of Payne \& Morris (1969) in which the oxaloacetate formed by PCx is converted to citrate by citrate synthase in the presence of acetyl-CoA and 5,5'-dithio-bis-2-nitrobenzoate. The activity in this assay was monitored by following the increase in $A_{412}$ due to CoA-dependent formation of 5-thio-2-nitrobenzoate. The second method was that of Milrad de Forchetti \& Cazzulo (1976), in which the oxaloacetate formed by PCx is converted to malate by malate dehydrogenase in the presence of NADH. The decrease of NADH was monitored at $340 \mathrm{~nm}$. The third method was the discontinuous GOT-coupled assay (Fisher \& Magasanik, 1984) described above for measuring the PCx activity in permeabilized cells. PCx from bovine liver (Sigma) and cell-free extracts prepared from Bacillus subtilis DB104 were used as positive controls.

PEPC $x$ and PEPCk were assayed photometrically at $30^{\circ} \mathrm{C}$ as described previously (Peters-Wendisch et al., 1993).

NMR spectroscopy and determination of ${ }^{13} \mathrm{C}$ enrichments. High-resolution ${ }^{1} \mathrm{H}-\mathrm{NMR}$ spectra of aspartate were obtained on a Bruker AMX-400 WB spectrometer operating at $400 \cdot 13 \mathrm{MHz}$ and equipped with a multichannel interface and a $5 \mathrm{~mm}$ inverse probe head. ${ }^{13} \mathrm{C}$ enrichments in $\mathrm{C}-2$ and $\mathrm{C}-3$ of aspartate were calculated from NMR spectra with and without ${ }^{13} \mathrm{C}$ decoupling using the parameters and the method described by Peters-Wendisch et al. (1996). ${ }^{13} \mathrm{C}$ enrichments in C-1 and C-4 of aspartate were quantified by spin echo ${ }^{1} \mathrm{H}$ NMR difference spectroscopy with and without selective ${ }^{13} \mathrm{C}$ inversion also according to the method described previously (Peters-Wendisch et al., 1996).

Western blot analysis. Cell-free extracts of C. glutamicum were prepared as described above. Equal amounts of heatdenatured cell extract protein were loaded and separated on an SDS-PAGE $(7.5 \%$ or $10 \%$ acrylamide, $\mathrm{w} / \mathrm{v} ; 10 \mathrm{~mA}$ for $14 \mathrm{~h}$ ) and electroblotted at $5 \mathrm{~mA} \mathrm{~cm}^{-2}$ for $30 \mathrm{~min}$ onto a polyvinylidene difluoride membrane (Millipore) using a Fast Blot 33 semidry transfer cell from Biometra. After blocking of the membrane with $1.5 \%(\mathrm{w} / \mathrm{v})$ bovine serum albumin in $50 \mathrm{mM}$ Tris/ $\mathrm{HCl}, \mathrm{pH} 7 \cdot 4,150 \mathrm{mM} \mathrm{NaCl}, 0 \cdot 1 \%$ (v/v) Tween 20 , the biotinylated proteins were detected using streptavidinlinked alkaline phosphatase from Boehringer Mannheim according to the instructions of the manufacturer.

\section{RESULTS}

\section{PCx activity in C. glutamicum}

Cell-free extracts of C. glutamicum grown on complex medium, and on minimal media containing glucose, lactate or acetate as carbon sources, were tested for PCx activity. Using the citrate-synthase-coupled and the malate-dehydrogenase-coupled assays and a variety of assay conditions, no PCx activity could be detected. Using the discontinuous GOT-coupled PCx assay, pyruvate- and ATP-dependent activity was observed; however, this activity decreased from about $40 \mathrm{nmol}$ $\min ^{-1}(\text { mg protein })^{-1}$ at the start of the reaction to about $4 \mathrm{nmol} \mathrm{\operatorname {min } ^ { - 1 }}$ (mg protein) ${ }^{-1}$ after $1 \mathrm{~min}$ and to $<1 \mathrm{nmol} \mathrm{\textrm {min } ^ { - 1 } ( \mathrm { mg } \text { protein) }}{ }^{-1}$ after $2 \mathrm{~min}$. In contrast, PCX activity could easily and reliably be demonstrated in cell-free extracts of $B$. subtilis with any of the three assays used (data not shown).
Table 1. ${ }^{13} \mathrm{C}$ enrichments in the $\mathrm{C}$ atoms of aspartate derived from different pyruvate carboxylase assays with permeabilized cells of $C$. glutamicum

\begin{tabular}{|lrrrr|}
\hline Substrate & \multicolumn{4}{c|}{$\begin{array}{c}\text { Percentage }{ }^{13} \mathrm{C} \\
\text { enrichments in } \\
\text { aspartate* }\end{array}$} \\
\cline { 2 - 5 } & C-1 & C-2 & C-3 & C-4 \\
\hline $\mathrm{HCO}_{3}^{-}+\left[2-{ }^{13} \mathrm{C}\right]$ pyruvate $(70 \%)$ & $1 \cdot 1$ & $70 \cdot 0$ & $1 \cdot 1$ & $1 \cdot 1$ \\
$\mathrm{HCO}_{3}^{-}+\left[3-{ }^{13} \mathrm{C}\right]$ pyruvate $(70 \%)$ & $1 \cdot 1$ & $1 \cdot 1$ & $68 \cdot 0$ & $1 \cdot 1$ \\
$\mathrm{H}^{13} \mathrm{CO}_{3}^{-}(99 \%)+$ pyruvate & $1 \cdot 1$ & $1 \cdot 1$ & $1 \cdot 1$ & $98 \cdot 0$ \\
\hline
\end{tabular}

*Values are means of two determinations. Absolute errors are $<0.5 \%$.

In a further attempt to reliably demonstrate $\mathrm{PCx}$ activity in C. glutamicum, we tested permeabilized cells. For this purpose, C. glutamicum WT cells were suspended in HEPES buffer containing $0.3 \%$ CTAB and then subjected to the GOT-coupled PCx assay. C. glutamicum cells grown on minimal medium containing lactate as carbon source displayed specific aspartate-forming activity of $45 \pm 5 \mathrm{nmol} \mathrm{min}^{-1}(\mathrm{mg} \text { dry wt })^{-1}$. That the observed reaction represented PCx activity was indicated by its linear dependence on cell concentration (up to $2 \mathrm{mg}$ dry wt per assay), incubation time (up to $5 \mathrm{~min}$ ), and the presence of $\mathrm{Mg}^{2+}$ and the substrates pyruvate, ATP and $\mathrm{HCO}_{3}^{-}$. The activity in either HEPES, Tris/HCl, MES or MOPS buffer was approximately the same and optimal over a $\mathrm{pH}$ range of $7 \cdot 0$ to $7 \cdot 5$. The reaction rates at different pyruvate concentrations followed Michaelis-Menten kinetics with a $K_{\mathrm{m}}$ value of $1.3 \mathrm{mM}$ and a $V_{\max }$ of $50 \mathrm{nmol} \mathrm{min}{ }^{-1}(\mathrm{mg} \text { dry wt })^{-1}$. The $K_{\mathrm{m}}$ value for ATP was $0.2 \mathrm{mM}$. ADP, AMP and ITP inhibited the PCx activity with inhibition constants of $2.6 \mathrm{mM}, 0.75 \mathrm{mM}$ and $15 \mathrm{mM}$, respectively. Additionally, the C. glutamicum PCx activity was efficiently inhibited by acetyl-CoA with a $K_{\mathrm{i}}$ value of $110 \mu \mathrm{M}$.

To prove that the aspartate formed by the permeabilized cells originates from pyruvate and $\mathrm{HCO}_{3}^{-}$, i.e. from carboxylation of the methyl group of pyruvate, we performed the GOT-coupled assay in the presence of either $\left[2-{ }^{13} \mathrm{C}\right]$ pyruvate plus unlabelled $\mathrm{HCO}_{3}^{-}$, [3${ }^{13} \mathrm{C}$ )pyruvate plus unlabelled $\mathrm{HCO}_{3}^{-}$or unlabelled pyruvate plus $\mathrm{H}^{13} \mathrm{CO}_{3}^{-}$, and analysed the purified aspartate by ${ }^{1} \mathrm{H}-\mathrm{NMR}$. As shown in Table 1, the assays with $70 \%$ enriched $\left[2-{ }^{13} \mathrm{C}\right]$ pyruvate or $\left[3-{ }^{13} \mathrm{C}\right]$ pyruvate resulted in about $70 \%{ }^{13} \mathrm{C}$ enrichments in aspartate $\mathrm{C}-2$ and $\mathrm{C}-3$, respectively, and the assay with $99 \%$ $\mathrm{H}^{13} \mathrm{CO}_{3}^{-}$resulted in $98 \%{ }^{13} \mathrm{C}$ enrichment in the $\mathrm{C}-4$ carboxyl group of aspartate. This labelling pattern was expected in the case of direct carboxylation of pyruvate to oxaloacetate and subsequent conversion to aspartate by GOT. Thus, we conclude that aspartate formation in permeabilized C. glutamicum cells was due to $\mathrm{PCx}$ activity.

To test whether PCx in C. glutamicum is regulated by 

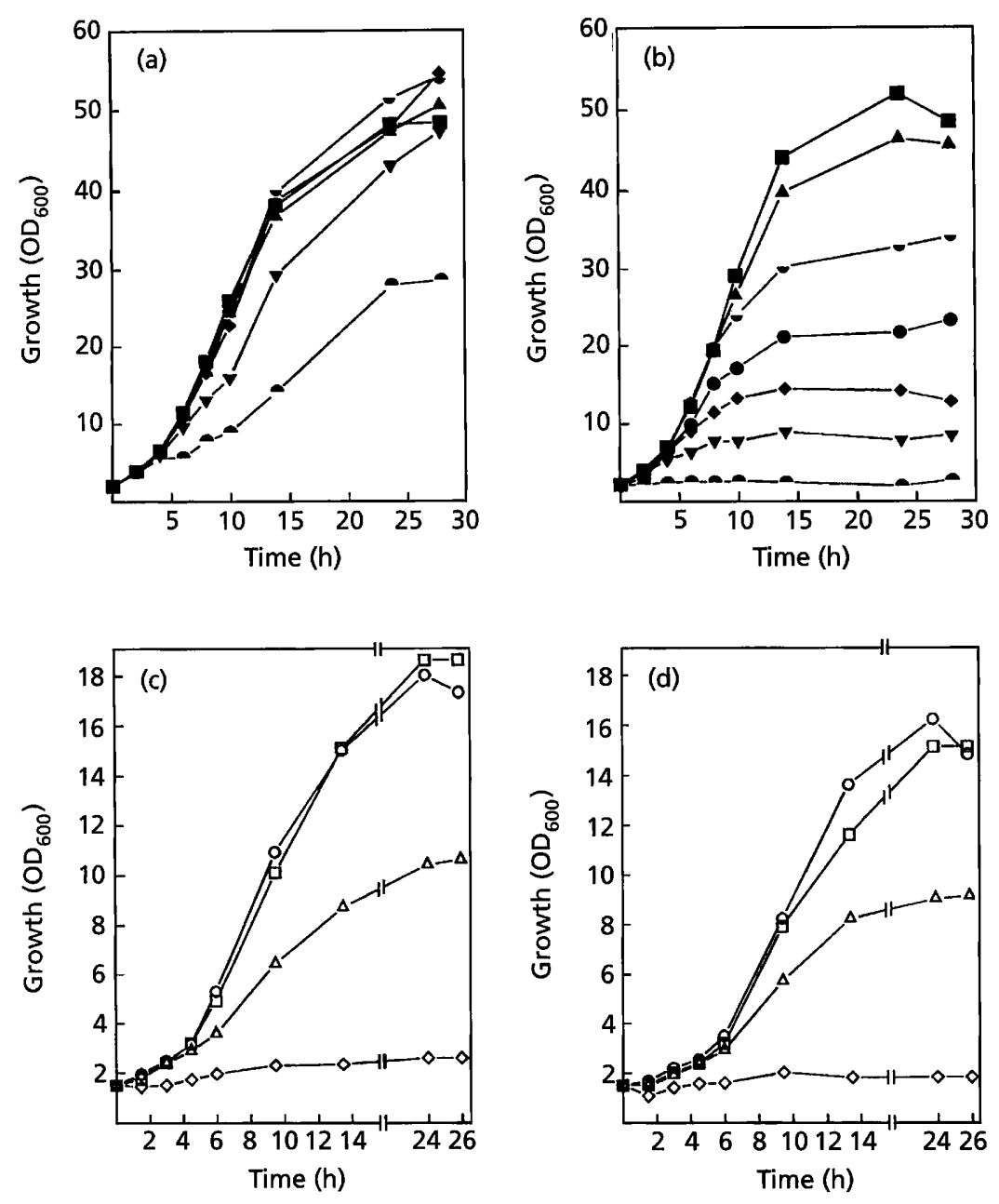

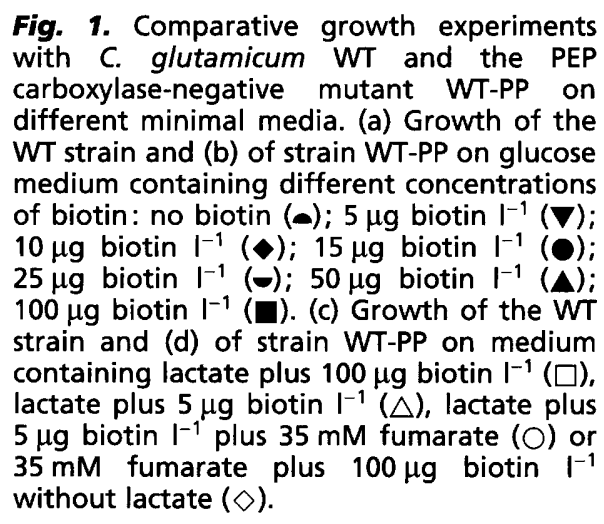

the carbon source, the effect of different growth substrates on the specific activity of the enzyme was determined. The highest activity $\left[45 \pm 5 \mathrm{nmol} \mathrm{min}{ }^{-1}\right.$ $(\mathrm{mg} \text { dry wt })^{-1}$ ] was found in cells grown on lactate or pyruvate; it was significantly lower when the cells were

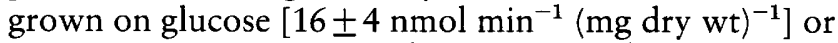
acetate $\left[19 \pm 4 \mathrm{nmol} \mathrm{m^{-1 }}\left(\mathrm{mg} \mathrm{dry} \mathrm{wt}^{-1}\right]\right.$. These results suggest that $C$. glutamicum $\mathrm{PCx}$ is regulated by the carbon source, and that the enzyme is more important for C. glutamicum during growth on lactate or pyruvate than on the other two substrates.

The PCx activity was also determined with cells of the PEPCx-negative mutant C. glutamicum WT-PP and of the L-lysine producer $\mathrm{MH} 20-22 \mathrm{~B}$. Both strains showed the same specific PCx activities as C. glutamicum WT.

\section{Effect of biotin on the growth of C. glutamicum}

All PCx enzymes examined so far contain covalently bound biotin as a prosthetic group (Scrutton \& Young, 1972). To study whether biotin has an effect on the growth of C. glutamicum, especially on that of the PEPCx-negative mutant WT-PP, we compared growth under biotin limitation and excess. As shown in Fig. $1(a, b)$, growth of the mutant strain on glucose was considerably more dependent on biotin (optimal at $>50 \mu$ g biotin $\mathrm{l}^{-1}$ ) than growth of the WT (optimal at $>5 \mu \mathrm{g}$ biotin $\left.\mathrm{l}^{-1}\right)$. These results show that for growth on glucose the demand of C. glutamicum for biotin is significantly higher in the absence of PEPCx than in its presence. In contrast, with lactate as carbon source, the WT and the PEPCX-negative mutant showed about the same high demand for biotin (e.g. in Fig. 1c, d). However, when fumarate at $35 \mathrm{mM}$ was added to the medium with growth-limiting concentrations of biotin, growth of both strains was completely restored (Fig. $1 c, d)$. Since neither strain grew on fumarate as the only carbon source, these results indicate that a biotindependent reaction or pathway in C. glutamicum can be circumvented by supplying the cells with the TCA cycle intermediate fumarate. For optimal growth on acetate as carbon source, both the WT and the PEPCx-negative strain required less than $5 \mu \mathrm{g}$ biotin $\mathrm{l}^{-1}$ (data not shown). Assuming that the C. glutamicum $\mathrm{PCx}$ is a biotin enzyme, these results indicate that (i) $\mathrm{PCx}$ is essential as an anaplerotic enzyme for growth on glucose in the absence of PEPCx, (ii) PCx is essential as an anaplerotic enzyme for growth on lactate even in the presence of PEPCx, and (iii) PCx has no anaplerotic function during growth on acetate. 

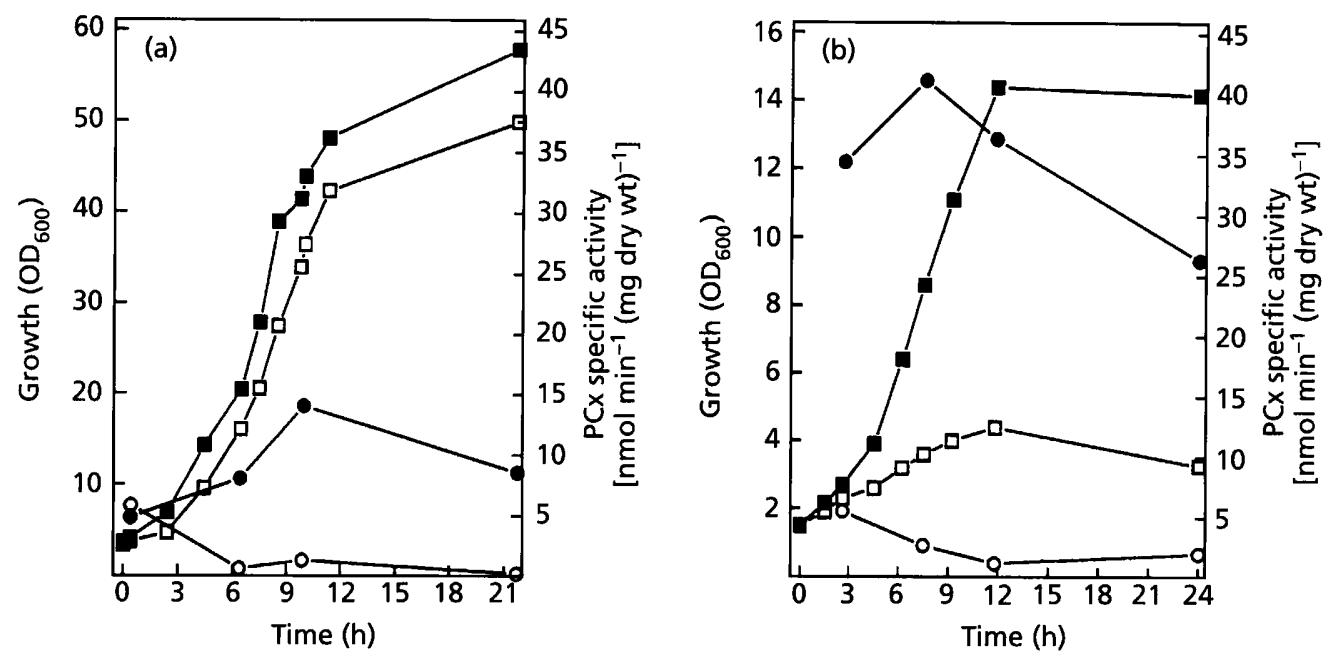

Fig. 2. Growth (squares) and specific pyruvate carboxylase (PCx) activity (circles) of $C$. glutamicum WT on glucose medium

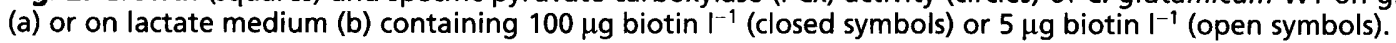

(a)

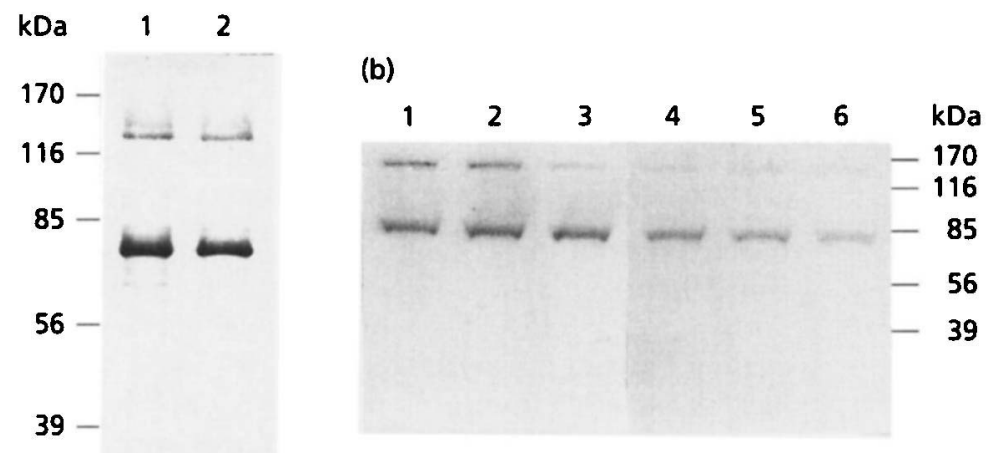

27

Fig. 3. (a) Western blot of SDS-PAGE of cellfree extracts $(20 \mu \mathrm{g}$ protein each) of $C$. glutamicum WT (lane 1) and of the PEPcarboxylase-negative mutant WT-PP (lane 2) grown on glucose medium. (b) Western blot of SDS-PAGE of cell-free extracts $(10 \mu \mathrm{g}$ protein each) of C. glutamicum WT grown on lactate medium containing $100 \mu \mathrm{g}$ biotin $\mathrm{I}^{-1}$ (lanes 1-3) and $5 \mu \mathrm{g}$ biotin $\mathrm{I}^{-1}$ (lanes 4-6). The extracts were prepared $5 \mathrm{~h}$ (lanes 1 and 4), $12 \mathrm{~h}$ (lanes 2 and 5) and $24 \mathrm{~h}$ (lanes 3 and 6) after start of the growth experiment. The sizes and positions of protein molecular mass markers are indicated.

\section{Effect of biotin on the PCx activity of C. glutamicum}

To investigate whether there is a correlation between the biotin concentration in the growth medium and the PCx activity of C. glutamicum, we cultured WT cells on glucose medium supplemented with $100 \mu \mathrm{g}$ biotin $\mathrm{l}^{-1}$ or $5 \mu \mathrm{g}$ biotin $\mathrm{l}^{-1}$, and determined their specific PCx activity. The cells showed approximately the same growth on both media; however, the PCx activity of cells growing on the medium with $5 \mu \mathrm{g}$ biotin $\mathrm{I}^{-1}$ was significantly lower than that of the cells growing in the presence of $100 \mu \mathrm{g}$ biotin $\mathrm{l}^{-1}$ (Fig. 2a). The same experiments were performed on media containing lactate as the carbon source (Fig. 2b). Under biotin excess, i.e. when the growth of C. glutamicum was optimal, the specific PCx activity was relatively high. In contrast, under biotin limitation, i.e. when the growth of $C$. glutamicum was severely impaired, the specific PCx activity was drastically reduced. These data support the idea that $\mathrm{PCx}$ is a biotin protein and corroborate the conclusion that PCx is not essential as an anaplerotic enzyme for growth of C. glutamicum WT on glucose, but is essential for growth on lactate.

\section{Identification of biotinylated proteins in C. glutamicum}

Cell-free extracts of C. glutamicum WT and the PEP carboxylase-negative mutant WT-PP grown on glucose medium were assayed for biotinylated proteins by SDSPAGE and Western blot analysis. Two biotin-containing proteins, with approximate molecular masses of $65 \mathrm{kDa}$ and $125 \mathrm{kDa}$, were detected in both strains (Fig. 3a). Since the smaller protein represents the biotinylated subunit of an acyl-CoA carboxylase (Jäger et al., 1996) the $125 \mathrm{kDa}$ signal might correspond to the PCx.

To investigate whether there is a relation between 
Table 2. Specific activities of pyruvate carboxylase (PCX), PEP carboxylase (PEPCX) and PEP carboxykinase (PEPCK) in C. glutamicum R127, R127-SP078 and R127-SP733

PCx was determined in permeabilized cells, PEPCx and PEPCk in cell-free extracts of the respective C. glutamicum strain grown on glucose medium.

\begin{tabular}{|c|c|c|c|}
\hline \multirow[t]{2}{*}{ Strain } & \multicolumn{3}{|c|}{ Specific activity of: } \\
\hline & $\begin{array}{c}\text { PCx } \\
{\left[\mathrm{nmol} \mathrm{\textrm {min } ^ { - 1 }}\right.} \\
\left.(\mathrm{mg} \text { dry wt })^{-1}\right]\end{array}$ & $\begin{array}{c}\text { PEPCx } \\
{\left[\text { nmol min }^{-1}\right.} \\
\left.(\text { mg protein })^{-1}\right]\end{array}$ & 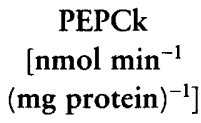 \\
\hline $\mathrm{R} 127$ & 15 & 231 & 165 \\
\hline R127-SP078 & 1.6 & 256 & 159 \\
\hline R127-SP733 & $<0.4$ & 262 & 175 \\
\hline
\end{tabular}

biotin-dependent growth, PCx activity and the $125 \mathrm{kDa}$ biotin protein, we tested C. glutamicum WT cells grown on lactate medium containing $100 \mu \mathrm{g}$ biotin $\mathrm{l}^{-1}$ or $5 \mu \mathrm{g}$ biotin $1^{-1}$ for their content of the $125 \mathrm{kDa}$ biotin protein. Under biotin excess, when the growth of C. glutamicum was optimal and the specific PCx activity was high (see Fig. 2b), significant amounts of the $125 \mathrm{kDa}$ biotin protein were present (Fig. 3b, lanes 1-3). In contrast, under biotin limitation, i.e. when the growth of $C$. glutamicum was severely impaired and PCx activity was almost not detectable, the $125 \mathrm{kDa}$ biotin protein was essentially absent (Fig. 3b, lanes 4-6). When the same experiments were performed with cells grown on media containing glucose, the $125 \mathrm{kDa}$ biotin protein was again present in the biotin-supplemented cells and not detectable in the biotin-limited cells. These results indicate that the biotinylated $125 \mathrm{kDa}$ protein of $C$. glutamicum probably represents the PCx enzyme.

\section{Isolation and characterization of PCx-negative C. glutamicum mutants}

To isolate PCx-negative mutants of C. glutamicum, mutagenized cells of the restriction-deficient strain R127 were plated on complex medium and about 40000 clones were screened for their ability to grow on solid medium with glucose or acetate but not lactate or pyruvate as carbon source. After retesting twice, 15 clones showing this phenotype were obtained. Permeabilized cells of these mutants were then tested for their specific PCx activity. When compared to the parental strain R127, 13 of the 15 showed between $50 \%$ and $100 \%$ PCx activity [i.e. $7 \cdot 5-14 \mathrm{nmol} \mathrm{min}{ }^{-1}$ (mg dry $w t)^{-1}$ ]. One mutant, designated R127-SP078, showed approximately $10 \% \mathrm{PCx}$ activity and one, designated R127-SP733, was devoid of any PCx activity (Table 2). These two strains were further tested for PEPCx and PEPCk activities and for their growth phenotype in liquid medium. Cell-free extracts of both mutants showed about the same levels of PEPCX and PEPCk as the parental strain (Table 2) and both mutants grew well on liquid medium with glucose or acetate but did not grow with lactate or pyruvate as carbon source. However, when lactate or pyruvate medium was supplemented with $35 \mathrm{mM}$ fumarate, both mutants showed the same growth as the parental strain in the absence of fumarate. These results suggested that the two isolates are not able to replenish the TCA cycle from lactate and pyruvate and thus, that the phenotype of strains R127SP733 and R127-SP078 is in fact due to the lack or drastic decrease in anaplerotic PCx activity.

\section{DISCUSSION}

Previous studies have shown that PEPCX is not essential as an anaplerotic enzyme for C. glutamicum (PetersWendisch et al., 1993; Gubler et al., 1994), and from ${ }^{13} \mathrm{C}$-labelling experiments and NMR analysis it was concluded that C. glutamicum must possess alternative anaplerotic activity that carboxylates either PEP or pyruvate (Peters-Wendisch et al., 1996). This conclusion has now been confirmed. The data reported here for the first time provide evidence that C. glutamicum possesses PCX as well as PEPCx, and they suggest that PCX functions exclusively as an anaplerotic enzyme during growth on lactate and pyruvate. In the PEPCX-negative mutant, $\mathrm{PCx}$ is obviously also responsible for the net synthesis of oxaloacetate during growth on glucose, and it might even be possible that PCx is the predominant anaplerotic enzyme in C. glutamicum WT during growth on glucose under biotin excess.

In having both PEPCx and PCx, C. glutamicum differs from Escherichia coli, B. subtilis and B. stearothermophilus. In E. coli, PEPCx represents the only anaplerotic enzyme during growth on glucose since a defined PEPCX-negative mutant is not able to grow on glucose as the sole carbon source and requires succinate as a supplement (Chao \& Liao, 1993). In B. subtilis and B. stearothermophilus, only PCx is responsible for the net formation of oxaloacetate. Mutants blocked in this enzyme were also unable to grow on minimal glucose or lactate media unless supplemented with TCA cycle intermediates (Diesterhaft \& Freese, 1973; Sundaram, 1973). Some bacteria, for example Pseudomonas citronellolis, P. fluorescens, Azotobacter vinelandii and Thiobacillus novellus, possess both PEPCx and PCx (O'Brien et al., 1977; Scrutton \& Taylor, 1974; Milrad de Forchetti \& Cazzulo, 1976; Charles \& Willer, 1984). However, to our knowledge it has not been determined whether in these bacteria one or the other of the two enzymes is essential under any given growth condition.

Previously, the presence of PCx has been reported in cell-free extracts of C. glutamicum subsp. lactofermentum (Tosaka et al., 1979), and there has been recent speculation that this enzyme might function in other C. glutamicum strains as well (Cocaign-Bousquet et al., 1996). However, in spite of intensive efforts, we and several other groups were unable to reliably measure PCx activity in cell-free extracts of this or any other $C$. glutamicum strain tested (Peters-Wendisch et al., 1993; Jetten et al., 1994; Gubler et al., 1994; CocaignBousquet \& Lindley, 1995; Cocaign-Bousquet et al., 
1996). This surprising finding could be due to instability of the enzyme under the chosen conditions, to loss of an enzyme component, or to loss of an activator molecule during preparation of the extract. PCx from some organisms, for example Arthrobacter globiformis, Aspergillus niger, chicken and rat liver, is very unstable under certain conditions $\left(\right.$ at $0^{\circ} \mathrm{C}, \mathrm{pH}$ values $>8$ or at low salt concentrations; in the case of A. globiformis due to structural changes in the native enzyme) (Gurr \& Jones, 1977; Feir \& Suzuki, 1969). However, the enzyme from other organisms is stable and easily measured (see, for example, Cazzulo et al., 1970; Scrutton \& Young, 1972; Scrutton \& Taylor, 1974; Modak \& Kelly, 1995). Biochemical and genetic approaches are now needed to find why PCx activity is difficult to measure in cell-free extracts of C. glutamicum.

The specific PCx activity in permeabilized cells of C. glutamicum depended on the growth medium and varied between $\quad 14-19 \mathrm{nmol} \mathrm{min}^{-1}(\mathrm{mg} \text { dry wt})^{-1}$ during growth on acetate or glucose and about $45 \mathrm{nmol} \mathrm{min}{ }^{-1}$ (mg dry wt $)^{-1}$ during growth on lactate or pyruvate. Assuming that approximately $50 \%$ of the dry weight consists of protein, these activities correspond to about 30 and $90 \mathrm{nmol} \mathrm{min}{ }^{-1}$ (mg protein $)^{-1}$, respectively, and thus are comparable to those observed in cell-free extracts of other organisms such as A. globiformis [90 nmol $\min ^{-1}$ (mg protein) $\left.)^{-1}\right]$, Rhizobium etli [50 $\mathrm{nmol} \mathrm{min}^{-1}$ (mg protein $\left.)^{-1}\right], T$. novellus $[25-100 \mathrm{nmol}$ $\min ^{-1}$ (mg protein) ${ }^{-1}$ ] or Rhodobacter capsulatus [20-

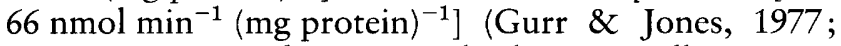
Encarnacion et al., 1995; Charles \& Willer, 1984; Willison, 1988). As in C. glutamicum, the specific PCx activity of some other organisms, for example $A$. vinelandii, $R$. sphaeroides, $R$. capsulatus and Saccharomyces cerevisiae, was three- to fourfold higher when the cells were grown on lactate instead of substrates such as glucose, glycerol, sucrose or malate (Scrutton \& Taylor, 1974; Payne \& Morris, 1969; Willison, 1988; Young et al., 1969) suggesting a pivotal anaplerotic role of PCx during growth on lactate. For C. glutamicum, this suggestion was substantiated by isolating a PCx-negative mutant due to its inability to grow on lactate (and pyruvate).

In its absolute requirement for $\mathrm{Mg}^{2+}$, its apparent $K_{\mathrm{m}}$ values of $1.3 \mathrm{mM}$ for pyruvate and $0.2 \mathrm{mM}$ for ATP and its sensitivity to AMP and ADP, the C. glutamicum PCx is similar to the PCx enzymes from other organisms (Milrad de Forchetti \& Cazzulo, 1976; Scrutton \& Taylor, 1974; Cazzulo et al., 1970; Gurr \& Jones, 1977; Modak \& Kelly, 1995). However, in contrast to all PCx enzymes studied so far, the C. glutamicum enzyme was inhibited by acetyl-CoA. Due to this feature, the $C$. glutamicum PCx does not conform to the classification of PCx enzymes by Scrutton \& Young (1972), which is based on the degree of activation of the enzyme by acetyl-CoA. Some PCx enzymes, for example those from $B$. subtilis, B. stearothermophilus and $R$. capsulatus, are strictly dependent on the presence of acetyl-CoA (Cazzulo et al., 1970; Diesterhaft \& Freese, 1973; Modak \& Kelly, 1995). The PCx enzymes of $A$. globiformis, T. novellus and $S$. cerevisiae are active without acetyl-CoA but they are stimulated significantly by it (Gurr \& Jones, 1977; Charles \& Willer, 1984; Ruiz-Amil et al., 1965), whereas those of $P$. fluorescens, $P$. citronellolis, A. vinelandii and A. niger are completely independent of acetyl-CoA (Milrad de Forchetti \& Cazzulo, 1976; Seubert \& Weicker, 1969; Scrutton \& Taylor, 1974; Feir \& Suzuki, 1969). The effective inhibition of the C. glutamicum PCx by acetyl-CoA together with the strong inhibition of the C. glutamicum PEPCx by aspartate (Eikmanns et al., 1989) might ensure that during growth of C. glutamicum on acetate or other precursors of acetyl-CoA the anaplerotic carboxylation reactions do not interfere with gluconeogenesis, i.e. with PEP and/or pyruvate formation from oxaloacetate by PEPCk and/or oxaloacetate decarboxylase. Both these enzymes have been found in $C$. glutamicum and shown to be formed under glycolytic as well as under gluconeogenetic conditions (Jetten \& Sinskey, 1993; Peters-Wendisch et al., 1993; Jetten \& Sinskey, 1995; Jetten et al., 1994). Since PEPCx and PCx are also formed under both conditions, a tight effectormodulated regulation of all the enzymes involved in interconverting PEP, pyruvate and oxaloacetate is required to properly adjust the carbon flux at this branch point within central metabolism, and to prevent extensive futile cycling. However, while the regulatory properties of the C. glutamicum PEPCx, PEPCk and oxaloacetate decarboxylase are well known [PEPCX is inhibited by aspartate and activated by acetyl-CoA and fructose-1,6-bisphosphate (Mori \& Shiio, 1985a, b; Eikmanns et al., 1989); PEPCk is inhibited by ADP and ATP (Jetten \& Sinskey, 1993); oxaloacetate decarboxylase is inhibited by ADP, CoA and succinate (Jetten \& Sinskey, 1995)], there are still some uncertainties about the regulation of PCx, since, for example, the effects of aspartate and 2-oxoglutarate, which both are potent inhibitors of PCx enzymes from some other organisms (e.g. Gurr \& Jones, 1977; Modak \& Kelly, 1995), could not be tested due to the principle of the GOT-coupled assay applied in this work.

Besides PEPCx, PEPCk, PCx and oxaloacetate decarboxylase, the decarboxylating/carboxylating enzymes located at the metabolic node around pyruvate in C. glutamicum include the NADP-dependent malic enzyme (Cocaign-Bousquet \& Lindley, 1995; Vallino \& Stephanopoulos, 1993). In principle, the reaction catalysed by this enzyme is reversible, but in most organisms the malic enzyme is assumed to catalyse the oxidative decarboxylation of malate rather than the reductive carboxylation of pyruvate (Kornberg, 1966). Although the role of the malic enzyme in C. glutamicum has never been clearly defined, Cocaign-Bousquet \& Lindley (1995) deduced from kinetic data of steady-state chemostat and batch cultures growing on lactate that the enzyme is involved in a metabolic cycle generating $\mathrm{NADPH}$ from $\mathrm{NADH}$ and thus provides reducing equivalents for anabolic metabolism. In this cycle, malate is decarboxylated to pyruvate by the NADPdependent malic enzyme, pyruvate is carboxylated to 
oxaloacetate by $\mathrm{PCx}$, and oxaloacetate is then reduced to malate by $\mathrm{NADH}$-dependent malate dehydrogenase. Our results indicating that $\mathrm{PCx}$ is exclusively responsible for the net synthesis of oxaloacetate in C. glutamicum WT during growth on lactate and in the PEPCx-negative mutant during growth on glucose agree with this model. They indicate that the malic enzyme does not catalyse the reductive carboxylation of pyruvate, and thus does not have an anaplerotic function under the conditions employed in this study.

It is evident that there is still a lot to be learned about $\mathrm{PCx}$, the anaplerotic carboxylation and the gluconeogenetic and/or NADPH-generating decarboxylation reactions in C. glutamicum. The isolation and characterization of the genes for PCx, PEPCk, oxaloacetate decarboxylase and malic enzyme, construction and analysis of defined mutants, and in vivo flux analyses are necessary to elucidate the regulatory network of the branchpoint between anaplerosis and gluconeogenesis in this industrially important organism.

\section{ACKNOWLEDGEMENTS}

We are grateful to $S$. Peters for preparing the photographs and M. Eikmanns and J. Carter Sigglow for critical reading of the manuscript. This work was supported by Degussa, the Bundesministerium für Bildung and Forschung, and by the Fonds der Chemischen Industrie.

\section{REFERENCES}

Cazzulo, J. J., Sundaram, T. K. \& Kornberg, H. L. (1970). Properties and regulation of pyruvate carboxylase from Bacillus stearothermophilus. Proc R Soc Lond B 16, 1-19.

Chao, Y.-P. \& Liao, J. C. (1993). Alteration of growth yield by overexpression of phosphoenolpyruvate carboxylase and phosphoenolpyruvate carboxykinase in Escherichia coli. Appl Environ Microbiol 59, 4261-4265.

Charles, A. M. \& Willer, D. W. (1984). Pyruvate carboxylase from Thiobacillus novellus: properties and possible functions. Can J Microbiol 30, 532-539.

Cocaign-Bousquet, M. \& Lindley, N. D. (1995). Pyruvate overflow and carbon flux within the central metabolic pathways of Corynebacterium glutamicum during growth on lactate. Enzyme Microb Technol 17, 260-267.

Cocaign-Bousquet, M., Guyonvarch, A. \& Lindley, N. D. (1996). Growth rate-dependent modulation of carbon flux through central metabolism and the kinetic consequences for glucoselimited chemostat cultures of Corynebacterium glutamicum. Appl Environ Microbiol 62, 429-436.

Diesterhaft, M. D. \& Freese, E. (1973). Role of pyruvate carboxylase, phosphoenolpyruvate carboxykinase and malic enzyme during growth and sporulation of Bacillus subtilis. J Biol Chem 248, 6062-6070.

Eikmanns, B. J., Follettie, M. T., Griot, M. U. \& Sinskey, A. J. (1989). The phosphoenolpyruvate carboxylase gene of Corynebacterium glutamicum: molecular cloning, nucleotide sequence, and expression. Mol Gen Genet 218, 330-339.

Eikmanns, B. J., Metzger, M., Reinscheid, D., Kircher, M. \& Sahm, H. (1991). Amplification of three theonine biosynthesis genes in Corynebacterium glutamicum and its influence on carbon flux in different strains. Appl Microbiol Biotechnol 34, 617-622.
Encarnacion, S., Dunn, M., Willms, K. \& Mora, J. (1995). Fermentative and aerobic metabolism in Rhizobium etli. $J$ Bacteriol 177, 3058-3066.

Feir, H. A. \& Suzuki, I. (1969). Pyruvate carboxylase of Aspergillus niger: kinetic study of a biotin-containing carboxylase. Can $J$ Biochem 47, 697-710.

Fisher, S. H. \& Magasanik, B. (1984). Synthesis of oxaloacetate in Bacillus subtilis mutants lacking the 2-ketoglutarate dehydrogenase enzymatic complex. J Bacteriol 158, 55-62.

Gornall, A. G., Bardawill, C. J. \& David, M. M. (1949). Determination of serum proteins by means of the biuret reaction. J Biol Chem 177, 751-766.

Gubler, M., Park, S. M., Jetten, M., Stephanopoulos, G. \& Sinskey, A. J. (1994). Effects of phosphoenolpyruvate carboxylase deficiency on metabolism and lysine production in Corynebacterium glutamicum. Appl Microbiol Biotechnol 40, 857-863.

Gurr, J. A. \& Jones, K. M. (1977). Purification and characterization of pyruvate carboxylase from Arthrobacter globiformis. Arch Biochem Biophys 179, 444-455.

Jäger, W., Peters-Wendisch, P. G., Kalinowski, J. \& Puhler, A. (1996). A Corynebacterium glutamicum gene encoding a twodomain protein similar to biotin carboxylases and biotincarboxyl-carrier proteins. Arch Microbiol 166, 76-82.

Jetten, M. S. M. \& Sinskey, A. J. (1993). Characterization of phosphoenolpyruvate carboxykinase from Corynebacterium glutamicum. FEMS Microbiol Lett 111, 183-188.

Jetten, M. S. M. \& Sinskey, A. J. (1995). Purification and properties of oxaloacetate decarboxylase from Corynebacterium glutamicum. Antonie Leeuwenhoek 67, 221-227.

Jetten, M. S. M., Pitoc, G. A., Follettie, M. T. \& Sinskey, A. J. (1994). Regulation of phospho(enol)-pyruvate- and oxaloacetateconverting enzymes in Corynebacterium glutamicum. Appl Microbiol Biotechnol 41, 47-52.

Kawamura, F. \& Doi, R. H. (1984). Construction of a Bacillus subtilis double mutant deficient in extracellular alkaline and neutral proteases. J Bacteriol 160, 442-444.

Kinoshita, S. (1985). Glutamic acid bacteria. In Biology of Industrial Microorganisms, pp. 115-142. Edited by A. Demain \& N. Solomon. London: Benjamin/Cummings Publishing.

Kornberg, H. L. (1966). Anaplerotic sequences and their role in metabolism. In Essays in Biochemistry, vol. 2, pp. 1-31. Edited by P. N. Campbell \& G. P. Greville. New York: Academic Press.

Krulwich, T. A. \& Pelliccione, N. J. (1979). Catabolic pathways of coryneforms, nocardias and mycobacteria. Ann Rev Microbiol 33, 95-111.

Liebl, W. (1991). The genus Corynebacterium - nonmedical. In The Prokaryotes, vol. II, pp. 1157-1171. Edited by A. Balows, H. G. Trüper, M. Dworkin, W. Harder \& K.-H. Schleifer. New York: Springer-Verlag.

Liebl, W. \& Schein, B. (1990). Isolation of restriction deficient mutants of Corynebacterium glutamicum. In DECHEMA Biotechnology Conferences, vol. 4, pp. 323-327. Edited by D. Behrens \& P. Krämer. Weinheim: Verlag Chemie.

Milrad de Forchetti, S. R. \& Cazzulo, J. J. (1976). Some properties of the pyruvate carboxylase from Pseudomonas fluorescens. J Gen Microbiol 93, 75-81.

Modak, H. V. \& Kelly, D. J. (1995). Acetyl-CoA-dependent pyruvate carboxylase from the photosynthetic bacterium Rhodobacter capsulatus: rapid and efficient purification using dye-ligand affinity chromatography. Microbiology 141, 2619-2628. 
Mori, M. \& Shiio, I. (1985a). Purification and some properties of phosphoenolpyruvate carboxylase from Brevibacterium flavum and its aspartate-overproducing mutant. $J$ Biochem 97, 1119-1128.

Mori, M. \& Shiio, I. (1985b). Synergistic inhibition of phosphoenolpyruvate carboxylase by aspartate and 2oxoglutarate in Brevibacterium flavum. J Biochem 98, 1621-1630.

O'Brien, R. W., Chuang, D. T., Taylor, B. L. \& Utter, M. F. (1977). Novel enzymic machinery for the metabolism of oxaloacetate, phosphoenolpyruvate and pyruvate in Pseudomonas citronellolis. J Biol Chem 252, 1257-1263.

Ozaki, H. \& Shiio, I. (1969). Regulation of the TCA and glyoxylate cycles in Brevibacterium flavum. J Biochem 66, 297-311.

Payne, J. \& Morris, J. G. (1969). Pyruvate carboxylase in Rhodopseudomonas sphaeroides. J Gen Microbiol 59, 97-101.

Peters-Wendisch, P. G., Eikmanns, B. J., Thierbach, G., Bachmann, B. \& Sahm, H. (1993). Phosphoenolpyruvate carboxylase in Corynebacterium glutamicum is dispensable for growth and lysine production. FEMS Microbiol Lett 112, 269-274.

Peters-Wendisch, P. G., Wendisch, V. F., de Graaf, A. A., Eikmanns, B. J. \& Sahm, H. (1996). $C_{3}$-Carboxylation as an anaplerotic reaction in phosphoenolpyruvate carboxylasedeficient Corynebacterium glutamicum. Arch Microbiol 165, 387-396.

Ruiz-Amil, M., deTorrontegui, G., Palacian, E., Catalina, L. \& Losada, M. (1965). Properties and functions of yeast pyruvate carboxylase. J Biol Chem 240, 3485-3492.

Sambrook, J., Fritsch, E. F. \& Maniatis, T. (1989). Molecular Cloning: a Laboratory Manual, 2nd edn. Cold Spring Harbor, NY : Cold Spring Harbor Laboratory.

Schobert, P. \& Bowien, B. (1984). Unusual C3 and C4 metabolism in the chemoautotroph Alcaligenes eutrophus. J Bacteriol 159, 167-172.
Schrumpf, B., Eggeling, L. \& Sahm, H. (1992). Isolation and prominent characteristics of an L-lysine hyperproducing strain of Corynebacterium glutamicum. Appl Microbiol Biotechnol 37, 566-571.

Scrutton, M. C. \& Taylor, B. L. (1974). Isolation and characterization of pyruvate carboxylase from Azotobacter vinelandii OP. Arch Biochem Biophys 164, 641-654.

Scrutton, M. C. \& Young, M. R. (1972). Pyruvate carboxylase. In The Enzymes, vol. 6, pp. 1-35. Edited by P. D. Boyer. New York: Academic Press.

Seubert, W. \& Weicker, H. (1969). Pyruvate carboxylase from Pseudomonas. Methods Enzymol 13, 258-262.

Sundaram, T. K. (1973). Physiological role of pyruvate carboxylase in a thermophilic bacillus. J Bacteriol 113, 549-557.

Tosaka, O., Morioka, H. \& Takinami, K. (1979). The role of biotindependent pyruvate carboxylase in L-lysine production. Agric Biol Chem 43, 1513-1519.

Vallino, J. J. \& Stephanopoulos, G. (1993). Metabolic flux distributions in Corynebacterium glutamicum during growth and lysine overproduction. Biotechnol Bioeng 41, 633-646.

Willison, J. C. (1988). Pyruvate and acetate metabolism in the photosynthetic bacterium Rhodobacter capsulatus. J Gen Microbiol 134, 2429-2439.

Wood, H. D. \& Utter, M. F. (1965). The role of $\mathrm{CO}_{2}$ fixation in metabolism. In Essays in Biochemistry, vol. 2, pp. 1-27. Edited by P. N. Campbell \& G. D. Greville. New York: Academic Press.

Young, M. R., Tolbert, B. \& Utter, M. F. (1969). Pyruvate carboxylase from Saccharomyces cerevisiae. Methods Enzymol $13,250-258$.

Received 21 August 1996; revised 12 November 1996; accepted 28 November 1996. 